University of Nebraska - Lincoln

DigitalCommons@University of Nebraska - Lincoln

Faculty Papers and Publications in Animal

Science

Animal Science Department

1993

\title{
Economical and Biological Efficiencies of Beef Cattle Differing in Level of Milk Production
}

M. van Oijen

Wageningen Agric. Univ., The Netherlands

M. Montano-Bermudez

Centro Nacional de Investig-a ciones en Fisiologia Y Mejoramiento Animal, Apartado Postal 29-A

Queretaro, QRO, Mexico

Merlyn K. Nielsen

University of Nebraska-Lincoln, mnielsen1@unl.edu

Follow this and additional works at: https://digitalcommons.unl.edu/animalscifacpub

Part of the Animal Sciences Commons

van Oijen, M.; Montano-Bermudez, M.; and Nielsen, Merlyn K., "Economical and Biological Efficiencies of Beef Cattle Differing in Level of Milk Production" (1993). Faculty Papers and Publications in Animal Science. 482.

https://digitalcommons.unl.edu/animalscifacpub/482

This Article is brought to you for free and open access by the Animal Science Department at DigitalCommons@University of Nebraska - Lincoln. It has been accepted for inclusion in Faculty Papers and Publications in Animal Science by an authorized administrator of DigitalCommons@University of Nebraska - Lincoln. 


\title{
Economical and Biological Efficiencies of Beef Cattle Differing in Level of Milk Production ${ }^{1}$
}

\author{
M. van Oijen ${ }^{2}$, M. Montaño-Bermudez ${ }^{3}$, and M. K. Nielsen ${ }^{4}$
}

Department of Animal Science, University of Nebraska, Lincoln 68583-0908

\begin{abstract}
Economical and biological efficiencies of beef production to weaning and to slaughter were estimated in three groups, different in milk available (low, medium, and high) to the calves but with the same potential for growth. Data from different breed groups of cows (low $[\mathbf{L}]=$ Hereford $\times$ Angus, medium $[\mathrm{M}]=$ Red Poll $\times$ Angus, and high $[\mathrm{H}]=$ Milking Shorthorn $\times$ Angus) were used. Economical efficiency was the ratio of income to expenses and biological efficiency was the ratio of calf weight to total feed energy required. Income was derived from cull cows and calves at weaning or carcasses of calves fed to slaughter. Feed and non-feed expenses for the cowherd and for calves to weaning or to slaughter were included in economical efficiency. Efficiencies were estimated assuming observed reproductive rates and energy requirements for maintenance, as well as for equal reproductive rates and equal energy requirements for maintenance in the $\mathrm{M}$ and $\mathrm{H}$ groups. With the observed reproductive rates and maintenance requirements, biological efficiencies to weaning and to
\end{abstract}

slaughter were $28.1,27.2$, and $27.5 \mathrm{~g}$ of weaning weight and 22.0,20.4, and $20.3 \mathrm{~g}$ of carcass weight per megacalorie of $\mathrm{ME}$ for $\mathrm{L}, \mathrm{M}$, and $\mathrm{H}$, respectively; the corresponding values using equal reproduction and equal maintenance in $\mathrm{M}$ and $\mathrm{H}$ were $28.3,27.2$, and $27.4 \mathrm{~g}$ of weaning weight and $22.1,20.5$, and $20.5 \mathrm{~g}$ of carcass weight per megacalorie of ME. Economical efficiencies (dollars of income $\times 100$ /dollars of expense) under the observed reproductive rates and maintenance requirements were $90.3,89.2$, and 88.1 to weaning and were $99.5,96.5$, and 95.3 to slaughter for $\mathrm{L}, \mathrm{M}$, and $\mathrm{H}$, respectively; under equal reproduction and equal maintenance in $M$ and $H$, the efficiencies at weaning were $91.0,88.4$, and 88.9 and at slaughter were $100.0,95.7$, and 95.1. Across the two scenarios, L was always the most economically efficient, especially when evaluated at slaughter of calves. Economical efficiency comparisons agreed closely with biological efficiency comparisons of the three cattle groups.

Key Words: Beef Cattle, Milk, Energy, Efficiency, Life Cycle

J. Anim. Sci. 1993. 71:44-50

\section{Introduction}

Economical efficiency is the ultimate criterion for comparison of alternative breeding programs. Earlier reports from an experiment at Nebraska have addressed performance of calf weight at weaning and at slaughter (Clutter and Nielsen, 1987), reproductive performance and cow weight changes (MontañoBermudez and Nielsen, 1990a), and maintenance

\footnotetext{
${ }^{1}$ Published as paper no. 9919, Journal Series, Nebraska Agric. Res. Div., Univ. of Nebraska, Lincoln 68583-0908.

${ }^{2}$ Present address: Wageningen Agric. Univ., $6700 \mathrm{AH}$, Wageningen, The Netherlands.

${ }^{3}$ Present address: Centro Nacional de Investigaciones en Fisiologia y Mejoramiento Animal, Apartado Postal 29-A, Queretaro, QRO, Mexico.

${ }^{4}$ To whom correspondence should be addressed.

Received April 8, 1992.

Accepted September 9, 1992.
}

energy requirements of cows (Montaño-Bermudez et al., 1990) differing in level of milk production. These were followed by a report on the biological efficiency to weaning and to slaughter of calves (Montaño-Bermudez and Nielsen, 1990b). The larger outputs of highermilking cows were offset by greater energy inputs, yielding biological efficiency estimates that usually favored the low-milking group, especially at slaughter of calves.

Economical efficiency had not been investigated in these previous studies. In addition, although the three groups of cows differed in level of milk, one group (medium) was smaller in size than the other two, which was not the intent of the project. Therefore, the first purpose of this paper was to estimate biological efficiency again with all groups of cows similar in mature size. The second purpose was to estimate economical efficiency for the three milk levels in beef production and to compare that to biological efficiency. 


\section{Materials and Methods}

\section{Source of Data}

Data for this study were obtained from a study conducted at the Dalbey-Halleck Farm in southeastern Nebraska. Hereford-Angus-cross cows represented low (L), Red Poll-Angus cross medium ( $\mathbf{M})$, and Milking Shorthorn-Angus cross high (H) levels of milk in cows, but all had similar genetic potential for calf growth and mature size of cows. Clutter and Nielsen (1987) and Montaño-Bermudez and Nielsen (1990a) described the experiment that generated the cattle measured, and Montaño-Bermudez et al. (1990) described the estimation of maintenance energy requirements of gestating and lactating cows.

Milk production, cow weight and calf birth weight, weaning weight, and postweaning gain data are shown in Table 1. Data on calf and cow weights in Table 1 for the $\mathrm{L}$ and $\mathrm{H}$ groups are as observed; the weight data for the $M$ group have been scaled up to match those of the $\mathrm{H}$ group (see Montaño-Bermudez and Nielsen [1990b] for observed weights for the $M$ group). Because $M$ and $H$ cows had the same mean condition score, the weights of $\mathrm{M}$ mature cows were

Table 1. Milk production of cows, mature weights of cows, and growth traits of calves from three milk-level groups

\begin{tabular}{|c|c|c|c|c|}
\hline \multirow[b]{2}{*}{ Trait } & \multirow{2}{*}{$\begin{array}{c}\text { Age of cow } \\
\text { at calving, } \\
y^{\mathrm{a}}\end{array}$} & \multicolumn{3}{|c|}{ Milk level } \\
\hline & & Low & Medium & High \\
\hline \multicolumn{5}{|l|}{ Cows } \\
\hline \multirow[t]{3}{*}{$\begin{array}{l}\text { 205-d Milk } \\
\text { production, kg }\end{array}$} & 2 & 990 & 1,355 & 1,511 \\
\hline & 3 & 1,227 & 1,568 & 1,730 \\
\hline & $4+$ & 1,285 & 1,632 & 1,879 \\
\hline $\mathrm{Wt}$, at $5+\mathrm{yr}, \mathrm{kg}$ & - & 553 & 513 & 513 \\
\hline \multicolumn{5}{|l|}{ Calves } \\
\hline \multirow[t]{2}{*}{ Birth wt, kg } & 2 & 35 & 34 & 34 \\
\hline & $3+$ & 39 & 38 & 38 \\
\hline \multirow[t]{3}{*}{ Weaning wt, kg } & 2 & 199 & 216 & 224 \\
\hline & 3 & 222 & 233 & 240 \\
\hline & $4+$ & 243 & 248 & 259 \\
\hline \multicolumn{5}{|c|}{ Postweaning ADG, $\mathrm{kg}^{\mathrm{b}}$} \\
\hline \multicolumn{5}{|l|}{ Growing period } \\
\hline \multirow[t]{2}{*}{ Males } & 2 & 1.00 & .96 & 1.02 \\
\hline & $3+$ & 1.15 & 1.06 & 1.10 \\
\hline \multirow{2}{*}{ Females } & 2 & .85 & .82 & .85 \\
\hline & $3+$ & .96 & .95 & .94 \\
\hline \multicolumn{5}{|l|}{ Finishing period } \\
\hline \multirow[t]{2}{*}{ Males } & 2 & 1.26 & 1.23 & 1.19 \\
\hline & $3+$ & 1.35 & 1.29 & 1.28 \\
\hline \multirow[t]{2}{*}{ Females } & 2 & 1.05 & 1.02 & .99 \\
\hline & $3+$ & 1.12 & 1.12 & 1.08 \\
\hline
\end{tabular}

${ }^{a}$ Females bred to bulls of their respective sire breed (Hereford, Red Poll, or Milking Shorthorn) at age 1 yr to produce backcross calves. Females bred to Charolais bulls at age $2+$ to yr to produce terminal-cross calves.

${ }^{\mathrm{b}}$ Feedlot conditions to slaughter. set equal to those of $\mathrm{H}$ mature cows $(513 \mathrm{~kg})$. Mean weights and gains of $M$ calves, preweaning and postweaning, were calculated relative to those of $\mathrm{H}$ calves using the regression of weight or gain on milk level. Thus, differences due to milk were retained, and those due to direct genetic effects were removed. Differences remain in cow weights, reflecting differences in fatness; whereas the $\mathrm{M}$ and $\mathrm{H}$ cows were the same in condition score, the $\mathrm{L}$ cows were fatter (Montaño-Bermudez and Nielsen, 1990a; MontañoBermudez et al., 1990). These data were then used to calculate the efficiencies of three groups of cattle that differed in level of milk but not in potential for growth. Calf-crop percentages and energy requirements for maintenance per unit of metabolic body weight for mature cows and growing cattle, reflecting those observed in the experiment (Montaño-Bermudez and Nielsen, 1990b), are listed in Table 2.

\section{Biological Efficiency of Beef Production}

Calculations were based on a simulated 1,000-cow herd of first-cross cows using the same modeling procedures and assumptions used by Montaño-Bermudez and Nielsen (1990b) for a 100-cow herd. The age composition ( 1 to $8 \mathrm{yr}$ ) of the breeding herd was estimated using the procedure described by Azzam et al. (1990). Probabilities of retention of cows of a given age were determined by corresponding calf-crop percentages. In this experiment, cows were culled if not pregnant in the fall or not nursing a calf at the beginning of the spring breeding season. Probabilities of survival of 3-yr-old and older cows, up to $8 \mathrm{yr}$, were pooled to account for the confounding of year and age effects. Heifers were mated to their respective sire breeds (backcrosses) to minimize calving difficulty, and cows were mated to Charolais bulls (terminal crosses). All calves were sold either at weaning or at slaughter. Replacement heifer calves were purchased at weaning.

Estimated inputs and outputs were weighted by percentages of cows of different ages in the herd and corresponding pregnancy rates, calving rates, or calfcrop percentages, depending on the scenario. Carcass weight was estimated assuming that steers were slaughtered at $499 \mathrm{~kg}$ if backcrosses and 535 if terminal (Charolais) crosses, and heifers at 460 and $490 \mathrm{~kg}$, respectively. Dressing percentages were obtained from animals produced in the experiment. Determination of feed energy costs were as described in detail by Montaño-Bermudez and Nielsen (1990b). Energy costs included components for maintenance, reproduction, milk production, and tissue gain or loss of the different ages of breeding animals and for maintenance and tissue gain in calves.

Efficiency was calculated using the observed reproductive rates and energy requirements for maintenance per metabolic size. Differences in reproductive rate across the three groups (Montaño-Bermudez and 
Table 2. Reproductive performance and maintenance energy requirements under the two scenarios for cattle of three milk-level groups

\begin{tabular}{|c|c|c|c|c|c|c|}
\hline \multirow[b]{2}{*}{ Trait } & \multicolumn{3}{|c|}{$\begin{array}{l}\text { Observed reproduction } \\
\text { and maintenance }\end{array}$} & \multicolumn{3}{|c|}{$\begin{array}{l}\text { Equal reproduction } \\
\text { and maintenance }\end{array}$} \\
\hline & $\begin{array}{c}\text { Low } \\
\text { milk level }\end{array}$ & $\begin{array}{l}\text { Medium } \\
\text { milk level }\end{array}$ & $\begin{array}{l}\text { High } \\
\text { milk level }\end{array}$ & $\begin{array}{l}\text { Low } \\
\text { milk level }\end{array}$ & $\begin{array}{l}\text { Medium } \\
\text { milk level }\end{array}$ & $\begin{array}{l}\text { High } \\
\text { milk level }\end{array}$ \\
\hline \multicolumn{7}{|c|}{ Calf-crop percentage, $\%$} \\
\hline $1-y r-o l d ~ \operatorname{cows}^{b}$ & 73.6 & 92.5 & 81.3 & 84.2 & 84.2 & 84.2 \\
\hline 2 -yr-old cows & 78.7 & 80.6 & 83.8 & 81.1 & 81.1 & 81.1 \\
\hline $3+-y r-o l d$ cows & 93.2 & 90.4 & 87.1 & 90.1 & 90.1 & 90.1 \\
\hline \multicolumn{7}{|c|}{$\begin{array}{l}\text { Energy for maintenance, } \\
\quad \mathrm{kcal} \cdot \mathrm{kg}^{-.75} \cdot \mathrm{d}^{-1 \mathrm{c}}\end{array}$} \\
\hline \multicolumn{7}{|l|}{ Mature cows } \\
\hline Gestation & 97 & 114 & 110 & 97 & 112 & 112 \\
\hline Lactation & 126 & 148 & 141 & 126 & 145 & 145 \\
\hline \multicolumn{7}{|l|}{ Growing cattle } \\
\hline Backcrosses & 132 & 145 & 150 & 132 & 147 & 147 \\
\hline Charolais crosses & 144 & 157 & 164 & 144 & 160 & 160 \\
\hline
\end{tabular}

Nielsen, 1990a), as well as differences in requirements for maintenance per metabolic size (BW.75) between the $\mathrm{M}$ and $\mathrm{H}$ groups (Montaño-Bermudez et al., 1990), were small and nonsignificant in most cases. Thus, efficiency was also estimated assuming an average reproductive efficiency and age composition in breeding animals, and using average maintenance requirements per metabolic size of $\mathrm{M}$ and $\mathrm{H}$ groups.

\section{Economical Efficiency of Beef Production}

Economical efficiency to weaning and to slaughter was defined as the ratio of dollars output to dollars input. Income from calves sold at weaning and cows culled during an annual cycle was the output used to estimate the economical efficiency to weaning. For the scenario of calves sold at slaughter, income from carcasses of the calves and from cull-cow sales was the output used. Inputs for the scenario of selling calves at weaning consist of the feed cost for the cowherd, the non-feed cost for the cowherd, and the cost for the purchase of replacement heifers entering the herd as newly weaned calves. Prices for purchase of replacement heifers were derived under the same assumptions as prices received for weaned heifers that were sold. For estimation of the inputs required for selling calves at slaughter, feed cost and non-feed cost for the calves during the postweaning period were added to the expenses at weaning.

Weaning income was estimated by using inflationadjusted, 10-yr average October prices. For that purpose the average weaning weights for heifers and steers were divided into weight groups with different prices per hundred weight, assuming a normal distribution (standard deviation $=23 \mathrm{~kg}$ ), following the procedure reported by Werth et al. (1991). For example, steer calves were priced at $\$ 2.05 / \mathrm{kg}$ in the medium weight range and $\$ 1.93 / \mathrm{kg}$ in the heavy weight range. To estimate income at slaughter (July sales), the same procedure was followed, taking carcass quality (choice or select) into account. To estimate cull-cow income, different prices per hundred weight were used for cows culled at weaning $(\$ 1.05 /$ $\mathrm{kg}$ ) and at the beginning of the breeding season. Weights of the cows depended on the cows' age and breed, and all cull cows were assumed salvageable.

To estimate feed cost for the cowherd, four periods of various lengths within an annual cycle were considered (Montaño-Bermudez and Nielsen, 1990b). Period lengths were defined by the times when body weights were recorded. A portion of the total energy requirement of a cow-calf unit was assigned to every period, depending on the length of the period and the annual cycle or age of the breeding cow. Then, levels of feedstuffs actually fed were assigned to meet the energy requirements in these four periods. Prices (inflation-adjusted, 10-yr averages) were assigned on these feeds (summer pasture, \$15.81/animal unit month; winter pasture, \$7.91/animal unit month; prairie hay, $\$ 6.44 / 100 \mathrm{~kg}$; corn $\$ 11.55 / 100 \mathrm{~kg}$; range cube, $\$ 29.27 / 100 \mathrm{~kg}$; salt and mineral, $\$ 4.02 / \mathrm{cow})$. The cost for the feed requirements of a replacement heifer from weaning until the beginning of the breeding season was included in the cowherd feed cost.

The non-feed cost for the cowherd $(\$ 153.77 /$ cow $)$ was based on values reported by the Nebraska integrated reproduction management demonstration project (Rasby et al., 1989). The non-feed cost for the replacement heifers from purchase to the breeding season was also included in the cowherd non-feed cost. 
Interest on purchase cost of replacement heifers was charged at $8 \%$ ( $12 \%$ minus $4 \%$ inflation adjustment), and interest on medical, facilities, and purchased feed costs was charged at $6 \%$ (12\% for one-half year, the midpoint of accumulating expenses). Labor, capital facilities, death loss, and management expenses were also charged. Non-feed costs (medical, facilities, machinery, labor, interest, and miscellaneous totalling $\$ 177.24 /$ heifer) were described by Frasier (1990). The cost of purchase of heifers for replacement at weaning was equal to the value of the same heifer calves at weaning.

The cost to feed the calves from weaning to slaughter was based on the energy requirements for this period and a price per megacalorie of $\mathrm{ME}$, estimated by combining the prices of the different amounts of feedstuffs. Data from Jose (1990) were used to derive the non-feed cost (medical, yardage, and miscellaneous) for the postweaning period. Interest was charged at $12 \%$ for $150 \mathrm{~d}$ (slightly more time than one-half the feeding period).

\section{Results and Discussion}

\section{Biological Outputs, Inputs, and Efficiencies}

Table 3 lists the weaning and carcass weights, the $\mathrm{ME}$ required for cows and calves, and the biological efficiency. Calf weaning weight output was 6 and $5 \%$ greater by $\mathrm{M}$ and $\mathrm{H}$, respectively, than by the $\mathrm{L}$ group under the observed scenario. These advantages reflect both calf weight differences due to dam's milk and small differences in reproductive rate. Under equal reproduction, the $M$ and $H$ produced 4 and $8 \%$ more output, respectively. Differences in carcass output reflect only reproductive and, with much less impact, dressing percentage differences. Hence, little difference was seen in the scenario of equal reproductive rate.

In both variations of reproduction and maintenance energy, the $\mathrm{L}$ group required the least energy for production to weaning and slaughter. Energy for the cowherd to weaning was 14 and $12 \%$ higher for $\mathrm{M}$ and $H$, respectively, than for the $L$ group under observed reproduction and maintenance. When equal reproductive rates for all groups and equal maintenance per metabolic size for the $\mathrm{M}$ and $\mathrm{H}$ groups were assumed, energy for the cowherd to weaning was 11 and $15 \%$ higher for $\mathrm{M}$ and $\mathrm{H}$ groups, respectively. The $\mathrm{M}$ and $\mathrm{H}$ groups required 9 and 5\% more energy to slaughter than did the $\mathrm{L}$ group, under the observed scenario, and 7 and $8 \%$, respectively, when equal reproduction and maintenance ( $M$ and $H$ groups) were assumed.

Biological efficiency of production to weaning was the highest for the $\mathrm{L}$ group in both cases. The efficiency was similar for the $\mathrm{M}$ and $\mathrm{H}$ groups. When the efficiency was measured until slaughter, L was also the most efficient group and the $\mathrm{M}$ and $\mathrm{H}$ groups had equal efficiencies. Differences in inputs contributed more to variation in efficiency than those in outputs. This is in contrast to the relationship found within a breed type by Freking and Marshall (1991). They reported that increasing milk yield tended to improve biological efficiency to weaning.

Table 3. Biological outputs (calf weaning or slaughter weights), inputs

(energy fed directly to cows and calves), and efficiencies per cow exposed to breeding for cattle of three milk-level groups

\begin{tabular}{|c|c|c|c|c|c|c|}
\hline \multirow[b]{2}{*}{ Component } & \multicolumn{3}{|c|}{$\begin{array}{l}\text { Observed reproduction } \\
\text { and maintenance }\end{array}$} & \multicolumn{3}{|c|}{$\begin{array}{l}\text { Equal reproduction } \\
\text { and maintenance }\end{array}$} \\
\hline & $\begin{array}{l}\text { Low } \\
\text { milk level }\end{array}$ & $\begin{array}{l}\text { Medium } \\
\text { milk level }\end{array}$ & $\begin{array}{c}\text { High } \\
\text { milk level }\end{array}$ & $\begin{array}{l}\text { Low } \\
\text { milk level }\end{array}$ & $\begin{array}{l}\text { Medium } \\
\text { milk level }\end{array}$ & $\begin{array}{l}\text { High } \\
\text { milk level }\end{array}$ \\
\hline \multicolumn{7}{|l|}{ Outputs, $\mathrm{kg}$} \\
\hline Weaning wt & 201 & 214 & 212 & 202 & 210 & 218 \\
\hline Carcass wt & 271 & 274 & 262 & 273 & 272 & 274 \\
\hline \multicolumn{7}{|l|}{ Inputs, Mcal $\left(\times 10^{3}\right) \mathrm{b}$} \\
\hline Cows & 6.11 & 6.94 & 6.82 & 6.11 & 6.77 & 7.04 \\
\hline $\begin{array}{l}\text { Calves from sources } \\
\text { other than milk }\end{array}$ & 1.04 & .95 & .92 & 1.04 & .95 & .93 \\
\hline Total to weaning & 7.15 & 7.89 & 7.74 & 7.15 & 7.72 & 7.97 \\
\hline Calves postweaning & 5.16 & 5.51 & 5.17 & 5.19 & 5.52 & 5.38 \\
\hline Total to slaughter & 12.31 & 13.40 & 12.91 & 12.34 & 13.24 & 13.35 \\
\hline \multicolumn{7}{|l|}{ Biological efficiency } \\
\hline Weaning & 28.1 & 27.2 & 27.5 & 28.3 & 27.2 & 27.4 \\
\hline Slaughter ${ }^{d}$ & 22.0 & 20.4 & 20.3 & 22.1 & 20.5 & 20.5 \\
\hline
\end{tabular}

${ }^{a}$ Equal reproduction for all three groups; equal maintenance in medium and high groups, but different from the low group.

Metabolizable energy.

${ }^{c}$ Calf weaning weight per total cow and calf energy, grams per megacalorie.

${ }^{\mathrm{d}}$ Calf carcass weight per total cow and calf energy, grams per megacalorie. 
Table 4. Distribution of expenses for 1,000-cow herds of three milk-level groups

\begin{tabular}{|c|c|c|c|c|c|c|}
\hline \multirow[b]{2}{*}{ Expense } & \multicolumn{3}{|c|}{$\begin{array}{l}\text { Observed reproduction } \\
\text { and maintenance }\end{array}$} & \multicolumn{3}{|c|}{$\begin{array}{l}\text { Equal reproduction } \\
\text { and maintenance }\end{array}$} \\
\hline & $\begin{array}{c}\text { Low } \\
\text { milk level }\end{array}$ & $\begin{array}{l}\text { Medium } \\
\text { milk level }\end{array}$ & $\begin{array}{l}\text { High } \\
\text { milk level }\end{array}$ & $\begin{array}{c}\text { Low } \\
\text { milk level }\end{array}$ & $\begin{array}{l}\text { Medium } \\
\text { milk level }\end{array}$ & $\begin{array}{l}\text { High } \\
\text { milk level }\end{array}$ \\
\hline & \multicolumn{6}{|c|}{ Selling calves at weaning } \\
\hline Cowherd feed & $45.1^{\mathrm{c}}$ & 48.1 & 46.4 & 45.7 & 47.1 & 47.4 \\
\hline Cowherd non-feed & 39.3 & 38.3 & 38.1 & 39.6 & 38.3 & 37.8 \\
\hline Replacement heifer ${ }^{b}$ & 15.6 & 13.6 & 15.5 & 14.7 & 14.6 & 14.8 \\
\hline Cowherd feed & 30.5 & 31.8 & 31.8 & 30.5 & 31.4 & 32.0 \\
\hline Cowherd non-feed & 26.5 & 25.3 & 26.2 & 26.5 & 25.5 & 25.5 \\
\hline Replacement heifer ${ }^{b}$ & 10.5 & 9.0 & 10.7 & 9.8 & 9.7 & 10.0 \\
\hline Postweaning feed & 18.8 & 20.1 & 18.2 & 19.2 & 19.7 & 19.1 \\
\hline Postweaning non-feed & 13.7 & 13.9 & 13.2 & 14.0 & 13.6 & 13.3 \\
\hline
\end{tabular}

aEqual reproduction for all three groups; equal maintenance in medium and high groups, but different from the low group.

${ }^{\mathrm{b}}$ Cost of a purchased heifer at weaning.

cPercentage of the expenses within a calf-sales scenario.

\section{Expenses, Income, and Economical Efficiency}

The distribution of expenses is shown in Table 4. In all cases the percentages of the cowherd feed cost are the lowest for the $\mathrm{L}$ group. When the percentages of the cowherd and postweaning feed costs were added for the scenarios in which calves were sold at slaughter, the L group still had the lowest percentages. Estimated dollars for each source are not shown in Table 4; however, these can be derived from the data presented in Table 5 . Total expenses at weaning were 1 and $3 \%$ higher for $M$ and $H$ relative to $L$ under the observed performance; when equal reproduction and maintenance for $\mathbf{M}$ and $\mathrm{H}$ were assumed, expenses were 4 and $6 \%$ higher for $\mathrm{M}$ and $\mathrm{H}$ relative to $\mathrm{L}$. The respective values for expenses to slaughter were 3 and $2 \%$ under the observed and 4 and $4 \%$ under the adjusted performance.

Weaning, carcass, and cull-cow incomes per cow exposed to breeding are shown in Table 5. Under the observed reproductive rates, income from only weaned calves was highest for the $\mathbf{M}$ group, intermediate for

Table 5. Income (calves at weaning or slaughter plus cull cows), expenses (feed and non-feed for cows and calves), and economic efficiencies per cow exposed to breeding for cattle of three milk-level groups

\begin{tabular}{|c|c|c|c|c|c|c|}
\hline \multirow[b]{2}{*}{ Component } & \multicolumn{3}{|c|}{$\begin{array}{l}\text { Observed reproduction } \\
\text { and maintenance }\end{array}$} & \multicolumn{3}{|c|}{$\begin{array}{l}\text { Equal reproduction } \\
\text { and maintenance }\end{array}$} \\
\hline & $\begin{array}{c}\text { Low } \\
\text { milk level }\end{array}$ & $\begin{array}{l}\text { Medium } \\
\text { milk level }\end{array}$ & $\begin{array}{c}\text { High } \\
\text { milk level }\end{array}$ & $\begin{array}{c}\text { Low } \\
\text { milk level }\end{array}$ & $\begin{array}{l}\text { Medium } \\
\text { milk level }\end{array}$ & $\begin{array}{c}\text { High } \\
\text { milk level }\end{array}$ \\
\hline \multicolumn{7}{|l|}{ Income } \\
\hline \multicolumn{7}{|l|}{ Sell calves at weaning } \\
\hline Calves, $\$$ & 377.2 & 396.9 & 390.0 & 379.0 & 388.5 & 400.2 \\
\hline Cull cows, $\$$ & 119.2 & 96.7 & 111.1 & 110.9 & 105.0 & 105.0 \\
\hline Total, $\$$ & 496.4 & 493.6 & 501.1 & 489.9 & 493.5 & 505.2 \\
\hline \multicolumn{7}{|l|}{ Sell calves at slaughter } \\
\hline Carcasses, $\$$ & 690.9 & 711.7 & 678.3 & 694.9 & 696.5 & 695.6 \\
\hline Cull cows, $\$$ & 119.2 & 96.7 & 111.1 & 110.9 & 105.0 & 105.0 \\
\hline Total, $\$$ & 810.1 & 808.4 & 789.4 & 805.8 & 801.5 & 800.6 \\
\hline \multicolumn{7}{|l|}{ Expenses } \\
\hline Sell calves at weaning, $\$$ & 549.8 & 553.4 & 568.8 & 538.4 & 558.3 & 568.3 \\
\hline Sell calves at slaughter, $\$$ & 814.2 & 837.5 & 828.3 & 806.2 & 837.4 & 841.6 \\
\hline \multicolumn{7}{|l|}{ Economic efficiency ${ }^{b}$} \\
\hline Sell calves at weaning & 90.3 & 89.2 & 88.1 & 91.0 & 88.4 & 88.9 \\
\hline Sell calves at slaughter & 99.5 & 96.5 & 95.3 & 100.0 & 95.7 & 95.1 \\
\hline
\end{tabular}

aEqual reproduction for all three groups; equal maintenance in medium and high groups, but different from the low group.

$\mathrm{b}(\$ / \$) \times 100$. 


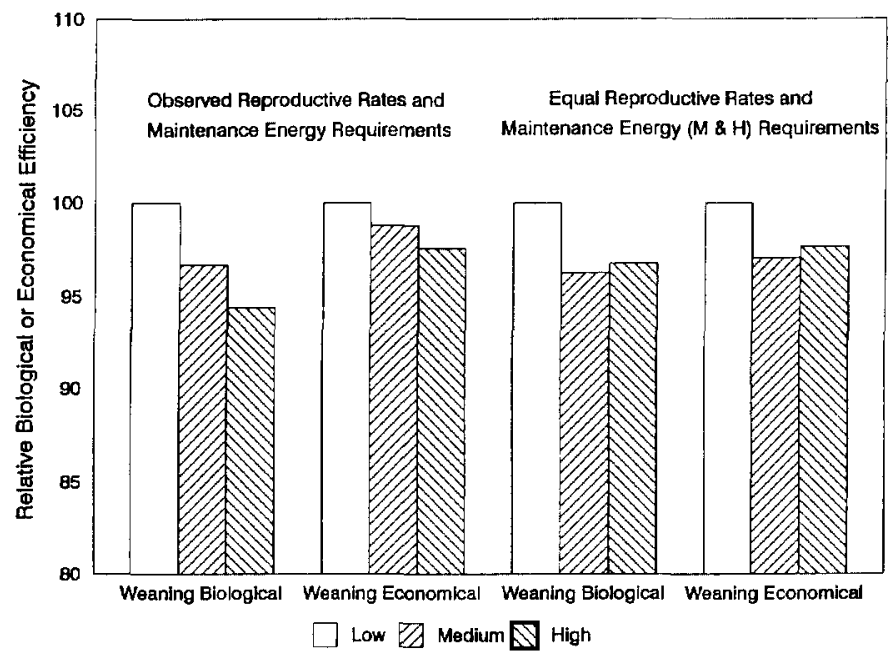

Figure 1. Biological and economical efficiencies at weaning under the two scenarios for beef cattle with three levels of milk production, medium and high relative to low $=100$.

$\mathrm{H}$, and lowest for $\mathrm{L}$. However, when equal reproductive rates were assumed, it was highest for $\mathrm{H}$, intermediate for $M$, and again lowest for $L$. The difference in reproductive rates between the $\mathrm{M}$ and $\mathrm{H}$ groups, under the observed scenario, offset an expected higher weaning income for $\mathrm{H}$ due to higher weaning weights.

Because the carcass weights were fixed, the differences in carcass income under the observed reproductive rates were mainly due to differences in reproductive rates. Therefore, the $M$ group had the highest carcass income and the $\mathrm{H}$ group the lowest, and there was hardly any difference between the three groups when equal reproductive rates were assumed.

The cull-cow income under the observed reproductive rates was the highest for the $\mathrm{L}$, intermediate for the $\mathrm{H}$, and lowest for the $\mathrm{M}$ group. This was mainly due to the fact that the $\mathrm{L}$ group had the highest replacement rate, and the $M$ group had the lowest. When equal reproductive rates were assumed, the $M$ and $\mathrm{H}$ groups had equal cull-cow income, and the $\mathrm{L}$ group had a higher income because of higher weights of the cull cows.

Economical efficiency of production to weaning (Table 5) was highest for the $L$ group in both scenarios. When efficiency was predicted through slaughter, it was also the highest for the $\mathrm{L}$ group in both cases; the difference between the $\mathrm{L}$ and the $\mathrm{M}$ and $\mathrm{H}$ groups was even increased. The $\mathrm{M}$ and $\mathrm{H}$ groups were similar in all cases. Differences in expenses contributed more to variation in efficiency than differences in incomes. Stokes et al. (1986), reporting the results from a simulation study, estimated that net returns were better for lower milk vs higher milk in beef herds selling calves at weaning.

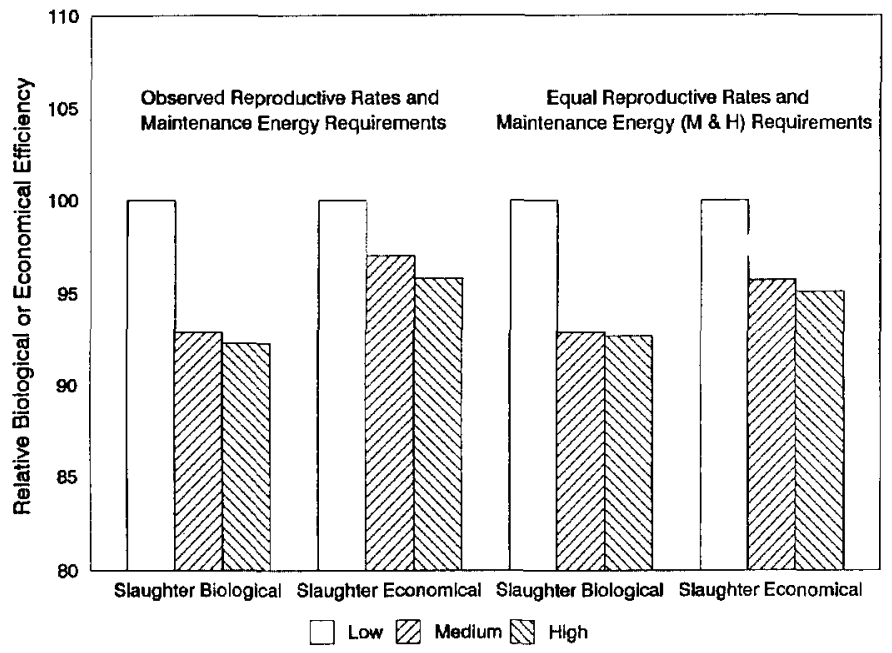

Figure 2. Biological and economical efficiencies at slaughter under the two scenarios for beef cattle with three levels of milk production, medium and high relative to low $=100$.

\section{Comparison of Economical to Biological Efficiency}

The results of the economical efficiency were similar to the results of the biological efficiency. Figure 1 shows the comparison of biological to economical efficiencies on a relative basis $(L=100)$ for the weaning end point. Figure 2 has the same comparison for the slaughter end point. Within each performance scenario for the weaning and slaughter evaluations, the groups ranked the same for biological and economical efficiencies.

For both economical and biological efficiencies, the higher outputs of the $\mathrm{M}$ and $\mathrm{H}$ groups were offset by higher inputs. The $\mathrm{M}$ and $\mathrm{H}$ groups were approximately 3 to $4 \%$ lower at weaning and $7 \%$ lower at slaughter than the $\mathbf{L}$ group for biological efficiency. Corresponding comparisons for economical ef iciency were 2 to $3 \%$ less at weaning and 4 to $5 \%$ less at slaughter. Although the relative difference was not quite as large at slaughter for economical efficiency, the $\mathrm{L}$ group remained ranked as the most efficient of the three. In this study for which the three groups were similar in pregnancy rate, dystocia, and calf survival and were all fed the same feedstuffs, biological efficiency was a much simpler calculation to yield the same results and conclusions than the more complicated, but complete, economical efficiency. Morris and Wilton (1975) stated that across different feeding and management schemes, breed groups would not be expected to give comparable results for economical and biological efficiency, noting that an economical evaluation was more complete. Notter et al. (1979) also found, in another simulation study, that economical efficiency did not necessarily correspond to biological efficiency to slaughter when 
compared across mature sizes and milk levels. But under the same feeding and management of this study, the two measures of efficiency agreed.

These results emphasize evaluation of breeds, crossing systems, and selection criteria for beef production cannot be done solely by measuring and considering output. Input must receive equal consideration, even though cost of measurement for new experiments and(or) lack of data from previous studies hamper research efforts. Feed costs, especially those for maintenance, are large and contribute greatly to variation in efficiency, as seen by the very close relationship of economical to biological (only input was feed energy) efficiencies in this study.

\section{Implications}

Variation in energy input (or herd expenses) contributed more to efficiency differences than did variation in calf output (or herd income) for cow groups differing in milk level. For cow-calf production, comparison of efficiency of breeding groups on a biological basis seems to be as complete as and easier than comparison on an economical basis. This was true when all groups ate the same feedstuffs, had the same fixed costs, and had similar levels of reproduction, dystocia, and survival. Recommendations to use breeds of cattle with high milk levels as dams in commercial production and to select for higher milking ability in beef breeds already with an adequate milk level are questionable.

\section{Literature Cited}

Azzam, S. M., A. M. Azzam, M. K. Nielsen, and J. E. Kinder. 1990. Markov chains as a shortcut method to estimate age distribu- tions in herds of beef cattle under different culling strategies. J. Anim. Sci. 68:5.

Clutter, A. C., and M. K. Nielsen. 1987. Effect of level of beef cow milk production on pre- and postweaning calf growth. J. Anim. Sci. 64:1313.

Frasier, W. M. 1990. Optimal management strategies for beef cattle herds in the sandhills area of Nebraska. M.S. Thesis. Univ. of Nebraska, Lincoln.

Freking, B. A., and D. M. Marshall. 1991. Interrelationships of milk production and other biological traits with production efficiency to weaning among first-calf heifers. J. Anim. Sci. 69(Suppl. 1): 67 (Abstr.).

Jose, H. D. (Ed.) 1990. Estimated Crop and Livestock Production Costs; 1990. Coop. Ext. Serv. Publ. No. 161. Univ. of Nebraska, Lincoln.

Montaño-Bermudez, M., and M. K. Nielsen. 1990a. Reproductive performance and variation in body weight during annual cycles for crossbred beef cows with different genetic potential for milk. J. Anim. Sci. 68:2289.

Montan̄o-Bermudez, M., and M. K. Nielsen. 1990b. Biological efficiency to weaning and to slaughter of crossbred beef cattle with different genetic potential for milk. J. Anim. Sci. 68:2297.

Montan̄o-Bermudez, M., M. K. Nielsen, and G. H. Deutscher. 1990. Energy requirements for maintenance of crossbred beef cattle with different genetic potential for milk. J. Anim. Sci. 68:2279.

Morris, C. A., and J. W. Wilton. 1975. Influence of mature cow weight on economic efficiency in beef cattle production. Can. J. Anim. Sci. 55:233.

Notter, D. R., J. O. Sanders, G. E. Dickerson, G. M. Smith, and T. C. Cartwright. 1979. Simulated efficiency of beef production for a Midwestern cow-calf-feedlot management system. I. Milk production. J. Anim. Sci. 49:70.

Rasby, R. J., W. M. Frasier, G. H. Deutscher, I. G. Rush, T. L. Mader, J. A. Gosey, and D. B. Hudson. 1989. Nebraska Integrated Reproductive Management Demonstration Project 1984-1989. Coop Ext. Serv. Publ. No. AnSci 89-1. Univ. of Nebraska, Lincoln.

Stokes, K. W., C. R. Shumway, P. E. Doren, W. O. Ajayi, T. C. Nelsen, and T. C. Cartwright. 1986. Economic effects of alternative beef cow size and milking potential in cow-calf operations. J. Anim. Sci. 62:1154.

Werth, L. A., S. M. Azzam, M. K. Nielsen, and J. E. Kinder. 1991. Use of a simulation model to evaluate the influence of reproductive performance and management decisions on net income in beef production. J. Anim. Sci. 69:4710. 